\title{
Regional Projection of Digital Economy
}

\author{
Novikova N.V.* Strogonova E.V. Dianova L.S. \\ Ural State University of Economics, Yekaterinburg, Russian Federation, \\ Corresponding author. Email: novikova@usue.ru
}

\begin{abstract}
In the modern scientific agenda, the discussion about the formation, development, and measurement of processes related to the digital economy comes to the fore. The main numbers of works devoted to the problems of the digital economy consider global and national processes. There is an acute lack of regional research, although processes occurring at the regional level form General trends on a national and global scale. The purpose of this research is to develop methodological tools for measuring the scale of the digital economy in the region (macroregion). The authors of the article propose a method for calculating the integral indicator of digitalization of the regional economy. The proposed methodology is based on twelve individual indicators, each of which characterizes the penetration of the digital economy and digital technologies into the territory of the region. The choice of indicators is justified by the authors. The article proves that the processes of deployment of the new industrialization of the Ural macroregion are closely related to the processes of digitalization.
\end{abstract}

Keywords: macroregion, digital economy, digitalization of the macroregion economy, Ural macroregion,

industry digitalization

\section{INTRODUCTION}

The digital economy is one of the latest intensively developing areas of economic science. In this regard, the conceptualization of the digitalization of the economy, its economic dimension cause heated debate in the modern scientific agenda.

Currently in the works of domestic and foreign authors attempts are made to reveal the content and quantitative measurement of the digital economy $[1,2,4-7,9,11,12$ etc.].

When conducting our own research, we relied on the conceptual provisions and methodology for identifying three levels of the digital economy, proposed by English scientists, representatives of the Institute for global development R. Bukht and R. Heeks [2]. They have prepared a detailed review of research on the digital economy to define, conceptualize and measure the scale of this phenomenon [2]. In the course of the research, R. Buckh and R. Heeks prove the existence of three levels of the digital economy.

They characterize the first level of the digital economy as follows: "The basis of the digital economy is the IT-sector, but the boundaries of the digital economy are not limited to it and cover some emerging digital business models" [2, p. 161]. As a result, the first level of the digital economy includes the digital (IT/ICT) sector, which integrates the production of components, information services, software and IT-consulting, and telecommunications (figure 1).

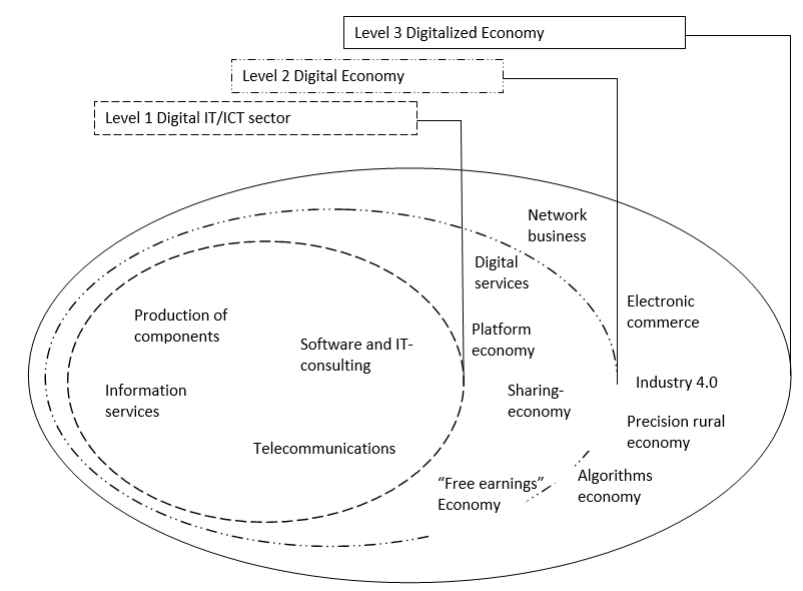

Figure 1 Three levels of the digital economy (by R. Bukht, R Heeks) [2, p. 155]

The second level of the digital economy adds to the first network business; digital services, as well as some promising elements of the digital economy, which include the platform economy, the economy of "free earnings" the gig-economy, the sharing-economy - those elements that are completely new economic activities that did not exist before the advent of the digital economy. For example, the authors included platform companies (Google, Facebook) in the second level; platform companies involved in the sale of real goods (Amazon, eBay and Alibaba); companies whose activities are at the junction of the traditional and digital economies, firms are digital platforms based on innovative digital technologies and digital business models (Uber, Airbnb).

The third level of the digital economy or "digitalized economy" is based on the use of digitized data in 
organizations and public processes (including economic activity). The third level covers network business (the implementation of business operations using ICT), electronic commerce (the implementation of external business operations using ICT), creating algorithms of the business decision-making process, the use of digital automation technologies in industry and agriculture, including "industry 4.0", precision rural economy and others.

The methodological basis for this research was also developed by Russian scientists, in particular the research team of the national research University Higher School of Economics (HSE). They summarized "key aspects of the development of the digital economy, trends in the development of digital technologies, changes in human living conditions under their influence, digitalization of public administration and the sphere of science" [13, p. 2]. For the first time, Russian researchers attempted to implement "original approaches to the statistical measurement of the digital economy", present "experimental calculations of the volume and structure of costs for its development in Russia", as well as "the contribution of the digital economy to economic growth" [13, p.2].

It should be noted that the study of the works of domestic and foreign authors has shown an acute lack of scientific research that reveals the regional aspect of the spread of the digital economy.

Summarizing the achievements of various scientific schools, we understand the digital economy as the totality of economic processes that arise as a result of activities to create, disseminate and use digital technologies and related products and services.

We understand digital technologies in the interpretation proposed by scientists at the Higher School of Economics as "technologies for the collection, storage, processing, retrieval, transmission and provision of data in electronic form" [13, p. 13].

Scientists at the Institute for Strategic Studies and Economics of Knowledge at the Higher School of Economics have proposed a methodology for calculating the business digitalization index, an integral indicator of the spread of digital technologies in the business sector. It characterizes "the speed of adaptation to digital transformation, the level of use of broadband Internet, cloud services, RFID-technologies, ERP-systems, the inclusion of business sector organizations in electronic commerce" [13, p. 10].

"ERP-system is an organization's resource planning system that includes one or more software applications that integrate information and production processes (functions) of organizational units. ERP-system integrates planning, procurement, sales, marketing, customer interaction, finance, human resources, etc.

RFID technologies are technologies for automatic identification of objects that allow to read or write data stored in RFID tags using radio signals "[3, p. 241].

\section{BACKGROUND}

The object of this study is the Ural macroregion, represented in accordance with the prevailing economic regionalization of the country, outlined by the borders of seven constituent entities of the Russian Federation Sverdlovsk, Chelyabinsk, Kurgan, Orenburg regions, Perm Territory, the Republic of Bashkortostan and the Udmurt Republic. Based on the statistical indicators proposed for the quantitative measurement of the digital economy by HSE scholars, we have compiled a table reflecting the digitalization indicators of business by the territories of the Ural macroregion (Table 1).

Table 1 Business Digitalization Indicators of the Russian Federation and territories of the Ural macroregion according to data for 2017

\begin{tabular}{|c|c|c|c|c|c|c|}
\hline \multirow{4}{*}{$\begin{array}{l}\text { Ural } \\
\text { macrore } \\
\text { gion } \\
\text { territori } \\
\text { es }\end{array}$} & \multirow{4}{*}{$\begin{array}{l}\text { Busines } \\
\text { s } \\
\text { Digitaliz } \\
\text { ation } \\
\text { Indicato } \\
\text { rs }\end{array}$} & \multicolumn{5}{|c|}{ Including Indicators Indices } \\
\hline & & \multicolumn{5}{|c|}{$\begin{array}{l}\text { share of organizations (in the total } \\
\text { number of organizations), } \%\end{array}$} \\
\hline & & \multicolumn{4}{|c|}{ using } & \multirow[b]{2}{*}{$\begin{array}{l}\text { mak } \\
\text { ing } \\
\text { onli } \\
\text { ne } \\
\text { sales }\end{array}$} \\
\hline & & $\begin{array}{l}\text { broad } \\
\text { band } \\
\text { intern } \\
\text { et }\end{array}$ & $\begin{array}{l}\text { clou } \\
\text { d } \\
\text { servi } \\
\text { ces } \\
\end{array}$ & $\begin{array}{l}\text { RFID- } \\
\text { technol } \\
\text { ogies }\end{array}$ & $\begin{array}{l}\text { ERP } \\
- \\
\text { syste } \\
\text { ms } \\
\end{array}$ & \\
\hline $\begin{array}{l}\text { Russian } \\
\text { Federati } \\
\text { on } \\
\end{array}$ & 28,0 & 82,0 & 23,0 & 6,0 & 19,0 & 12,0 \\
\hline \multicolumn{7}{|l|}{$\begin{array}{l}\text { Includin } \\
\text { g: }\end{array}$} \\
\hline $\begin{array}{l}\text { Republic } \\
\text { of } \\
\text { Bashkor } \\
\text { tostan } \\
\end{array}$ & 29,0 & 88,5 & 22,1 & 4,3 & 19,5 & 12,2 \\
\hline $\begin{array}{l}\text { Udmurt } \\
\text { Republic }\end{array}$ & 23,0 & 80,1 & 17,1 & 3,7 & 8,9 & 7,6 \\
\hline $\begin{array}{l}\text { Perm } \\
\text { Territor } \\
\mathbf{y}\end{array}$ & 27,0 & 84,5 & 23,1 & 4,6 & 13,4 & 9,7 \\
\hline $\begin{array}{l}\text { Orenbur } \\
\text { g region }\end{array}$ & 28,0 & 92,9 & 21,3 & 5,0 & 11,9 & 9,6 \\
\hline $\begin{array}{l}\text { Kurgan } \\
\text { region }\end{array}$ & 21,0 & 69,6 & 18,1 & 2,7 & 8,1 & 7,1 \\
\hline $\begin{array}{l}\text { Sverdlov } \\
\text { sk } \\
\text { region }\end{array}$ & 30,0 & 86,9 & 26,9 & 7,0 & 15,8 & 12,4 \\
\hline $\begin{array}{l}\text { Chelyabi } \\
\text { nsk } \\
\text { region }\end{array}$ & 28,0 & 85,4 & 23,4 & 5,1 & 13,7 & 11,3 \\
\hline
\end{tabular}

From the table data, we can see that the territories of the Urals are in different positions on the business digitalization index. The deviation is 9 points between the leader territory - Sverdlovsk region (30) and the outsider territory - Kurgan region (21).

The leading place among the territories of the Urals is occupied by the Sverdlovsk region (30), followed by the Republic of Bashkortostan (29), Orenburg and Chelyabinsk regions (28). Only two territories of the Ural macroregion - the Sverdlovsk region and the Republic of Bashkortostan exceed the average Russian value (28). 
In order to justify the factors of territorial differentiation of the digitalization level of business in the Ural regions, we have developed a methodology for calculating the integral indicator of digitalization of the regional economy. This task is complicated by the fact that the first attempts are being made to measure digitalization processes, and out of the whole set of indicators that are monitored by the Federal State Statistics Service, indirectly these processes most closely reflect the indicators characterizing information and communication technologies. According to the definition of the digital economy proposed by the English scientists R. Bukht and R. Heeks, information and communication technologies characterize the first level of the digital economy.

The method of calculation of integral indicators of digitalization of regional economy carried out the transformation of the partial indicators method of valuation metrics, which involves the calculation of the ratio values of the indicators for a particular region to the average in the group of regions considered (in our case in the macroregion).

To calculate the integrated indicator of digitalization of the regional economy, we used the method of aggregation of single transformed indicators by summing them. When summing, the indicators are assigned equal weights in order to avoid subjectivity in assigning weighted values.

Our calculations are based on 12 specific indicators, each of which characterizes the penetration of the digital economy and digital technologies into the territory of the region. Among the indicators, we will highlight the following:

- Organizations using personal computers, in \% of the total number of organizations examined in the corresponding

- Organizations using servers, in $\%$ of the total number of organizations examined in the corresponding subject of the Russian Federation.

- Organizations using local area networks, in \% of the total number of organizations examined in the corresponding subject of the Russian Federation.

- Organizations using broadband Internet access, in $\%$ of the total number of organizations examined in the corresponding subject of the Russian Federation.

- Organizations having a website, in \% of the total number of organizations examined in the corresponding subject of the Russian Federation.

- Number of personal computers per 100 employees, units

- Organizations using electronic document management systems, in $\%$ of the total number of organizations examined in the corresponding subject of the Russian Federation.

- Organizations using electronic data exchange between their and external information systems, in\% of the total number of organizations examined in the corresponding subject of the Russian Federation.
- Number of active subscribers of fixed broadband Internet access, per 100 population, at the end of the year, units.

- Number of active mobile broadband Internet subscribers, per 100 population, at the end of the year, units.

- Use of special software in organizations, in\% of the total number of organizations examined in the corresponding subject of the Russian Federation.

- Costs of information and communication technologies per one employed in the economy, thousand rubles / person

When forming a set of private indicators, we relied on the above definitions of the digital economy, digital technologies, and digitalization processes.

The dynamics of the selected indicators testifies to the active formation of the digital economy in the territory of the Ural macroregion (Fig. 2-6, table 2).

The increase in the share of organizations in the Urals that use servers looks very convincing. In 2003-2018, the indicator increased by $45.2 \%$ or 6.7 times - from $7.9 \%$ to $53.1 \%$ (Fig. 2). Currently, more than $53 \%$ of all organizations in the Urals, as well as in Russia as a whole, have their own servers. The curved lines shown in Fig. 2 indicate that the economic crisis of 2014 has intensified this process. In 2015, the increase in the value was 22.96 points.

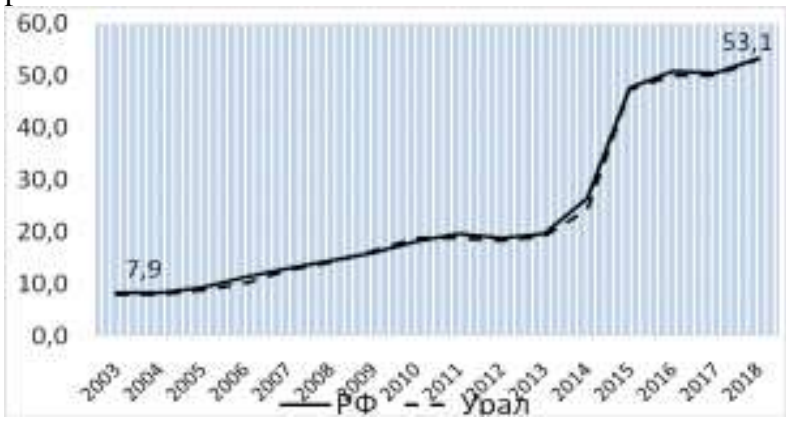

Figure 2 Dynamics of organizations in the Russian Federation and the Ural macroregion using servers, \% The share of organizations in the Ural macroregion and Russia as a whole that used broadband Internet access is steadily increasing (Fig. 3). In 2006-2018, the indicator value increased by $62.8 \mathrm{pp}$. or 3.6 times. Currently, more than $87.23 \%$ of all organizations in the Urals have such access, which allows them to reduce the time spent on operations, reduce transaction costs. 


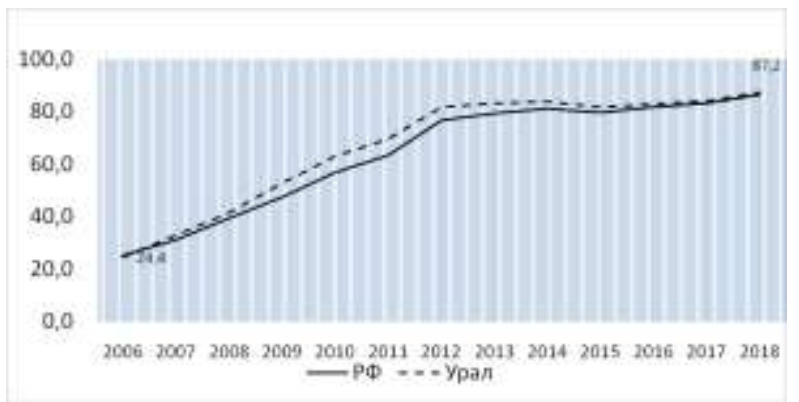

Figure 3 Dynamics of organizations in the Russian Federation and the Ural macroregion using broadband Internet access, $\%$

The specific value of Ural organizations that had a website increased 4.3 times over the period 2003-2018 from 11.9 $\%$ to $50.4 \%$ (Fig. 4). The website allows business entities to quickly convey information to contractors about their products (services), prices, and provide efficient communication.

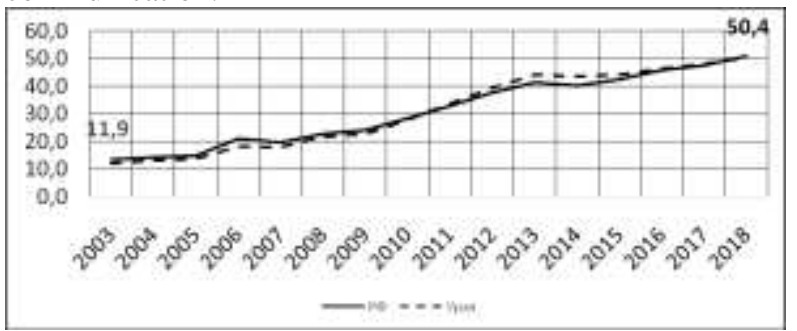

Figure 4 Dynamics of organizations in the Russian Federation and the Ural macroregion having a website, \% Trend lines reflecting the number of personal computers per 100 employees in the Russian Federation and the Urals have a fairly stable character (Fig. 5). Currently, 48 out of 100 employees in the Urals have a personal computer. In 2003 , there were only 15 such persons.

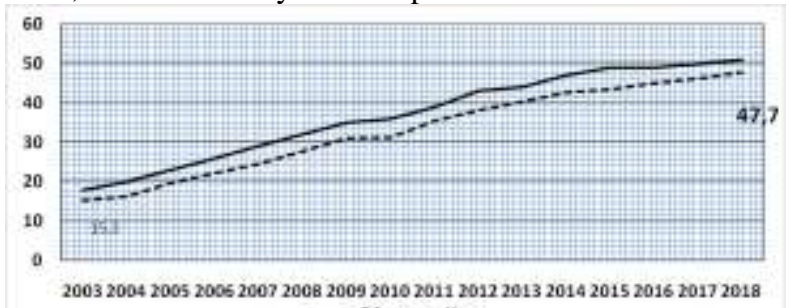

Figure 5 Dynamics of the number of personal computers per 100 employees of the Russian Federation and the Ural macroregion, pcs.
The presence of personal computers is the initial factor in the implementation of the digital economy, since they represent an important initial condition for the collection, storage, processing, retrieval, transmission and provision of data in electronic form - a condition for the use of digital technologies.

The presence of personal computers contributes to the growth of the share of organizations that actively use electronic data exchange between their own and external information systems. This indicator doubled over the seven years from 2011 to 2018 - from $33.3 \%$ to $66.7 \%$ (Fig. 5)

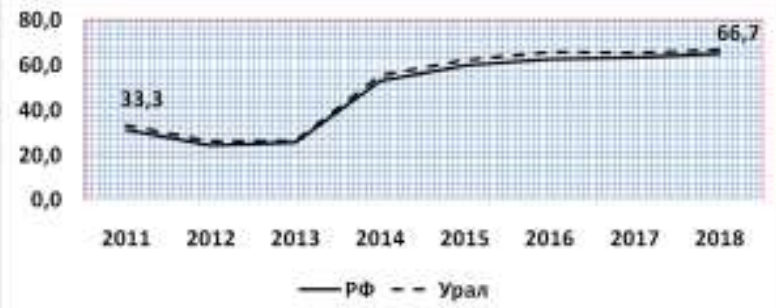

Figure 6 Dynamics of organizations that used electronic data exchange between their own and external information systems, \%

Dynamics of ten indicators of digitalization of the Russian economy and the economy of the Urals for the comparable period 2011-2018. (table. 2) revealed the largest growth in the macroregion of the following values:

- number of active subscribers of mobile broadband Internet access, per 100 population, by $35.63 \%$;

- $\quad$ share of organizations using servers - by 34.26 $\%$;

- $\quad$ share of organizations using electronic data exchange between their own and external information systems - by $33.42 \%$.

The transformed specific indicators and aggregated indicators of the level of digitalization of the regional economy calculated in the context of the territories of the Ural macroregion as of 2018 are shown in Table 3. 
Table 2 Dynamics of key indicators of digitalization of the Russian economy and the Ural microregion

\begin{tabular}{|c|c|c|c|c|c|c|c|c|c|}
\hline Indicator & 2011 & 2012 & 2013 & 2014 & 2015 & 2016 & 2017 & 2018 & $\begin{array}{l}\text { Change } \\
\text { in } 2018 \\
\text { compared } \\
\text { to } 2011\end{array}$ \\
\hline \multicolumn{10}{|l|}{$\begin{array}{l}\text { 1. Organizations using personal computers, in } \% \text { of the } \\
\text { total number of examined organizations }\end{array}$} \\
\hline Russian Federation & 94,1 & 94,0 & 94,0 & 93,8 & 92,3 & 92,4 & 92,1 & 94,0 & $-0,1$ \\
\hline Urals & 96,4 & 96,63 & 95,81 & 95,76 & 93,49 & 93,26 & 92,98 & 95,03 & $-1,36$ \\
\hline \multicolumn{10}{|l|}{$\begin{array}{l}\text { 2. Organizations using servers, in } \% \text { of the total number } \\
\text { of examined organizations }\end{array}$} \\
\hline Russian Federation & 19,7 & 18,9 & 19,7 & 26,6 & 47,7 & 50,8 & 50,6 & 53,4 & 33,64 \\
\hline Urals & 18,79 & 18,2 & 19,03 & 24,23 & 47,19 & 49,97 & 49,95 & $\mathbf{5 3 , 0 5}$ & 34,26 \\
\hline \multicolumn{10}{|l|}{$\begin{array}{l}\text { 3. Organizations using local area networks, in } \% \text { of the } \\
\text { total number of examined organizations }\end{array}$} \\
\hline Russian Federation & 71,3 & 71,7 & 73,4 & 67,2 & 63,5 & 62,3 & 61,1 & 63,9 & $-7,35$ \\
\hline Urals & 73,29 & 75,01 & 75,93 & 68,64 & 64,93 & 64,56 & 63,36 & 66,01 & $-7,28$ \\
\hline \multicolumn{10}{|l|}{$\begin{array}{l}\text { 4. Organizations using broadband Internet access, in \% of } \\
\text { the total number of examined organizations }\end{array}$} \\
\hline Russian Federation & 63,4 & 76,6 & 79,4 & 81,2 & 79,5 & 81,8 & 83,2 & 86,5 & 23,09 \\
\hline Urals & 69,3 & 81,67 & 83,14 & 83,63 & 81,57 & 82,73 & 83,99 & 87,23 & 17,93 \\
\hline \multicolumn{10}{|l|}{$\begin{array}{l}\text { 5. Organizations having a website, in } \% \text { of the total } \\
\text { number of examined organizations }\end{array}$} \\
\hline Russian Federation & 33,0 & 37,8 & 41,3 & 40,3 & 42,6 & 45,9 & 47,4 & 50,9 & 17,94 \\
\hline Urals & $\mathbf{3 3 , 5 7}$ & 39,34 & 44,23 & 43,59 & 44,1 & 46,54 & 48,09 & 50,42 & 16,85 \\
\hline \multicolumn{10}{|l|}{$\begin{array}{l}\text { 6. Number of personal computers per } 100 \text { employees, } \\
\text { units }\end{array}$} \\
\hline Russian Federation & 39 & 43 & 44 & 47 & 49 & 49 & 50 & 51 & 12 \\
\hline Urals & 35,29 & 38,14 & 40,14 & 42,57 & 43,29 & 44,86 & 46,14 & 47,71 & 12,43 \\
\hline \multicolumn{10}{|l|}{$\begin{array}{l}\text { 7. Organizations using electronic document management } \\
\text { systems, in } \% \text { of the total number of examined } \\
\text { organizations }\end{array}$} \\
\hline Russian Federation & 61,9 & 60,4 & 61,7 & 58,9 & 62,7 & 66,1 & 66,1 & 68,6 & 6,73 \\
\hline Urals & 68,7 & 67,39 & 66,64 & 67,67 & 67,46 & 68,86 & 67,64 & $\mathbf{7 0 , 4}$ & 1,7 \\
\hline \multicolumn{10}{|l|}{$\begin{array}{l}\text { 8. Organizations using electronic data exchange between } \\
\text { their and external information systems, in\% of the total } \\
\text { number of examined organizations }\end{array}$} \\
\hline Russian Federation & 31,3 & 24,3 & 25,7 & 52,7 & 59,6 & 62,4 & 63,1 & 64,9 & 33,61 \\
\hline Urals & $\mathbf{3 3 , 3}$ & 25,96 & 26,39 & 55,26 & 62,26 & 65,81 & 65,34 & 66,72 & 33,42 \\
\hline \multicolumn{10}{|l|}{$\begin{array}{l}\text { 9. Number of active subscribers of fixed broadband } \\
\text { Internet access, per } 100 \text { population, at the end of the year, } \\
\text { units. }\end{array}$} \\
\hline Russian Federation & 12,2 & 14,4 & 16,5 & 17,0 & 18,3 & 18,6 & 21,0 & 21,7 & 9,5 \\
\hline Urals & 12,53 & 15,17 & 17,23 & 17,77 & 18,83 & 18,89 & 21,33 & 21,79 & 9,26 \\
\hline \multicolumn{10}{|l|}{$\begin{array}{l}\text { 10. Number of active mobile broadband Internet } \\
\text { subscribers, per } 100 \text { population, at the end of the year, } \\
\text { units. }\end{array}$} \\
\hline Russian Federation & 47,8 & 52,6 & 59,8 & 64,5 & 68,1 & 71,1 & 79,9 & 86,2 & 38,4 \\
\hline Urals & 41,47 & 45,64 & $\mathbf{5 2 , 3 7}$ & 57,14 & 53,43 & $\mathbf{5 7 , 7 7}$ & 68,73 & $\mathbf{7 7 , 1}$ & $\mathbf{3 5 , 6 3}$ \\
\hline
\end{tabular}


Table 3 Transformed specific indicators and aggregated indicators of the level of digitalization of the regional economy calculated in the context of the territories of the Ural macroregion as of 2018.

\begin{tabular}{|c|c|c|c|c|c|c|c|}
\hline & $\begin{array}{l}\text { Organizations } \\
\text { using personal } \\
\text { computers, } \%\end{array}$ & $\begin{array}{l}\text { Organizations } \\
\text { using servers, } \\
\%\end{array}$ & $\begin{array}{l}\text { Organizations } \\
\text { using local area } \\
\text { networks, \% }\end{array}$ & $\begin{array}{l}\text { Organizations } \\
\text { using } \\
\text { broadband } \\
\text { Internet access, } \\
\%\end{array}$ & $\begin{array}{l}\text { Organizations } \\
\text { having } \\
\text { website, } \%\end{array}$ & $\begin{array}{l}\text { Number of } \\
\text { personal } \\
\text { computers } \\
\text { per } 100 \\
\text { employees, } \\
\text { units } \\
\end{array}$ & $\begin{array}{l}\text { Organizations } \\
\text { using electronic } \\
\text { data exchange, } \\
\%\end{array}$ \\
\hline $\begin{array}{l}\text { Republic of } \\
\text { Bashkortostan }\end{array}$ & 1,019 & 1,026 & 1,030 & 1,018 & 1,067 & 0,964 & 1,068 \\
\hline $\begin{array}{l}\text { Udmurt } \\
\text { Republic }\end{array}$ & 1,016 & 1,016 & 1,035 & 0,997 & 1,079 & 1,069 & 1,013 \\
\hline Perm Territory & 1,001 & 1,052 & 0,982 & 1,031 & 0,888 & 1,069 & 1,020 \\
\hline $\begin{array}{l}\text { Orenburg } \\
\text { region }\end{array}$ & 1,018 & 0,953 & 1,034 & 1,081 & 1,090 & 0,922 & 1,051 \\
\hline $\begin{array}{l}\text { Kurgan } \\
\text { region }\end{array}$ & 0,935 & 0,707 & 0,835 & 0,864 & 0,781 & 0,943 & 0,894 \\
\hline $\begin{array}{l}\text { Sverdlovsk } \\
\text { region }\end{array}$ & 1,013 & 1,137 & 1,034 & 1,016 & 1,051 & 1,048 & 0,968 \\
\hline $\begin{array}{l}\text { Chelyabinsk } \\
\text { region }\end{array}$ & 0,997 & 1,110 & 1,049 & 0,993 & 1,044 & 0,985 & 0,987 \\
\hline $\begin{array}{l}\text { Republic of } \\
\text { Bashkortostan }\end{array}$ & 0,904 & 0,987 & 0,987 & 1,003 & 1,048 & 12,120 & 1,010 \\
\hline $\begin{array}{l}\text { Udmurt } \\
\text { Republic }\end{array}$ & 1,003 & 0,941 & 0,984 & 0,982 & 0,606 & 11,742 & 0,978 \\
\hline Perm Territory & 1,267 & 1,005 & 1,023 & 0,999 & 1,350 & 12,689 & 1,057 \\
\hline $\begin{array}{l}\text { Orenburg } \\
\text { region }\end{array}$ & 1,051 & 0,835 & 1,058 & 1,027 & 0,589 & 11,709 & 0,976 \\
\hline $\begin{array}{l}\text { Kurgan } \\
\text { region }\end{array}$ & 0,795 & 0,936 & 0,874 & 1,000 & 0,457 & 10,022 & 0,835 \\
\hline $\begin{array}{l}\text { Sverdlovsk } \\
\text { region }\end{array}$ & 0,989 & 1,125 & 1,016 & 0,999 & 1,395 & 12,791 & 1,066 \\
\hline $\begin{array}{l}\text { Chelyabinsk } \\
\text { region }\end{array}$ & 0,991 & 1,170 & 1,057 & 0,989 & 0,739 & 12,111 & 1,009 \\
\hline
\end{tabular}

\section{CONCLUSION}

It should be noted that the results obtained by the authors largely coincide with the results of scientists at the Higher School of Economics (Table 1 and Table 3). However, our calculations have a large degree of scientific justification, because they are based on the use of a more solid set of indicator indicators characterizing not only the processes of business digitalization, but also the processes of digitalization of the regional economy as a whole.

The strategic guidelines for the development of the Ural macro-region are closely connected with the processes of digitalization of industrial production, which are "the integration of a number of breakthrough technologies: virtual modeling, the Internet of things, robotics, artificial intelligence, big data, cloud and boundary computing technologies, predictive analytics, new communication standards, etc. . " [13, p. 26]. Digitalization of industrial production, in turn, is one of the basic technologies of Industry 4.0, which, according to the methodology of R.
Bukht and R. Heeks, is part of the third level of the digital economy - the "digitalized economy" (Fig. 1).

Strategic industry and technological guidelines for the development of the Ural macroregion in the context of the digitalization of the economy, detailed in the scientific monograph by professors Silin Ya.P., Animitsa EG, Novikova N.V. "Ural macro-region: large cycles of industrialization" [10] and include the production of unmanned aerial vehicles (drones); production of robotics; additive technology; Information Technology; Internet of Things (IoT) technologies, (industrial Internet); bigdata, artificial intelligence; space technology. Before making decisions on identifying promising areas of digitalization of the regional economy, we must proceed from an analysis of the current situation. The tasks of analysis and strategy are the methodology proposed by the authors for calculating the integrated indicator of digitalization of the regional economy. In the future, it will require transformation due to the need to take into account the values of the second and third levels of the digital economy, which are currently still quite weakly measured. 
Analysis: Theory and Practice, 2017, vol. 16, iss. 12, pp. 2238-2253.

[13] What is the digital economy? Trends, competencies, measurement: dokl. By XX Apr. Int. scientific conf. on the problems of economic and social development / G. I. Abdrakhmanova, K. O. Vishnevsky, L. M. Gokhberg et al. - M.: Publishing House. Houseof the Higher School of Economics, 2019 . -248 p.

Measuring the Digital Economy, in: Bulletin of international organizations, vol. 13, iss. 2, 2017, pp. 143-172. DOI: 10.17323/1996-7845-2018-02-07.

[3] Digital Economy Indicators in the Russian Federation: 2019 : Data Book / G. Abdrakhmanova, K. Vishnevskiy, L. Gokhberg et al.; National Research University Higher School of Economics. Moscow: HSE, 2019.

[4] House of Commons. The Digital Economy. London: House of Commons Business, Innovation and Skills Committee,

2016 https://www.publications.parliament.uk/pa/cm201617/c mselect/cmbis/87/87.pdf (accessed at 5February 2020).

[5] Lane N. Advancing the digital economy into the 21 st century. Information Systems Frontiers, vol. 1, no 3, 1999, pp. 317-320.

[6] Mesenbourg T.L. Measuring the Digital Economy, US Bureau of the Census, Suitland, 2001. Available at: https://www.census.gov/content/dam/Census/library/wo rking- papers/2001/econ/umdigital.pdf (accessed at 10 February 2020).

[7] Schwab K. The fourth industrial revolution. Moscow: Publishing«Э», 2017. - 208 p.

[8] Schwab K., Davis N. Technology of the fourth industrial revolution. Moscow: Eksmo, 2018.- 320 p.

[9] SilinYa.P., AnimitsaYe.G. Contours of the digital economy in Russia, in Journal of the Ural State University of Economics, 2018, vol. 19, no. 3, pp. 18-25. DOI: 10.29141/2073-1019-2018-19-3-3

[10] SilinYa.P., AnimitsaYe.G., Novikova N.V. Ural macro-region: large cycles of industrialization. Yekaterinburg: Publishing House Ural. state econ. University, 2019. - 371 p.

[11] Tapscott D. The Digital Economy: Promise and Peril in the Age of Networked Intelligence. New York, NY: McGraw-Hill, 1996.

[12] Ustyuzhanina et al. Digital economy as a new paradigm of economic development, in: Economic
[12] Brennen S., Kreiss D. Digitization and digitalization [Text] / S. Brennen, D. Kreiss. - 2014

[13] Lane N. Promotion of the digital economy in the XXI century [Text] // Information systems, 1999.

[14] Negroponte N. Being digital [Text] / N. Negroponte. - NY: Knopf, 1995.

[15] Oxford English Dictionary online [Text] // Oxford University Press, 2019.

[16] Raus M. Digital Economy [Text] // Newton: Techtarget, 2016. 